\title{
Chang-rae Lee's A Gesture Life: The Recuperation of Identity
}

\section{Matthew Miller University of South Carolina Aiken}

In Chang-rae Lee's A Gesture Life, the elderly, wellrespected and fastidious Franklin "Doc" Hata begins an introspective journey toward a revitalized and reimagined identity. For Lee, this journey affords the chance to address ethnicity and immigration under a unique transnational context. The novel chronicles how an identity can be recuperated (i.e., healed) through personal and cultural reconnections to the body and to memory. I purposefully use the word "recuperate" in both the traditional and theoretical senses. "Recuperation" results from Hata's moving back into his past to grow forward in self. Simultaneously, he "heals" his self, physically and psychologically, from various "afflictions" he endures. By exploring Hata's various afflictions against the novel's ways to counteract these ailments, I will show how Lee's novel becomes a narrative of recuperation and identity change.

In his most powerful portrayal of the Asian American immigrant, A Gesture Life, Chang-rae Lee creates a 
character with multiple levels of Otherness: a transplanted Korean identifying himself as Japanese transplanted in America. These multilayered complications of identity make Hata's character ex-centric to the familiar paradigms of Asian American theory. Indeed, Young-Oak Lee locates this character within a postcolonial diagram: Hata is at once a colonizer and the colonized in an American territory of conflicted identities. Not quite in and not quite out, Hata, the successful businessman and yellow invader, still does not belong to America. ${ }^{1}$ Other critics and reviewers tend to evoke ideas of the limen when discussing identity and its construction in A Gesture Life. David Cowart describes Hata, a first generation American immigrant character, as living in an American limbo. He becomes neither "ethnic prima materia" nor "American alloy" (Cowart 80). ${ }^{2}$ In an interview from the New York Times, Lee explains his artistic investment: “'I'm interested in people who find themselves in places, either of their choosing or not, and who are forced to decide how best to live there. That feeling of both citizenship and exile, of always being an expatriate-with all the attendant problems and complications and delight'" (Garner). ${ }^{3}$ Franklin Hata perhaps translates his out-ofplace existence into several physical and psychological maladies which hinder self-actualization. Consequently, one can imagine Hata's "vexed identity" as "a membrane stretched over chopped and broken shards-their edges constantly threatening rupture" (Cowart 80). Hata, at least in the novel's beginning, is a walking trauma. ${ }^{4}$

Lee, however, establishes that even a Franklin Hata can rectify past ills through explorations of memory and reconnections with history and family. Lee's novel uses memory to retrieve loss and provide a chance to discover and promote the healing of self. Shoshana Felman and Dori Laub in Testimony: Crises of Witnessing in Literature, Psychoanalysis and History outline a similar process. Survivors tell stories or create testimonies that bridge the gaps in historical and personal memory. Through 
this telling the survivor bears witness: "The testimony is, therefore, the process by which the narrator (the survivor) reclaims his position as a witness: reconstitutes the internal 'thou,' and thus the possibility of a witness or a listener inside himself" (85). Although he is not the typical survivor, Hata's journey allows him to reclaim his self and provide history to a silent story. A Gesture Life shows that a character can move toward a fuller, healthier understanding of identity.

As a complicated diasporic figure, Hata cannot acculturate fully into either the adopted cultures of Japan and America, making him feel out of place in his environment. In both places, race is the limiting factor that impedes social acceptance. For instance, Captain Ono, his superior during World War Two, remarks that he knows Hata's Korean lineage even though Hata masks this identity in his Japanese life (222). While in America, his Japanese nationality gives a false sense of delight, exoticism, and a "town-affirming" mentality (2). Hata's role-playing both in Japan and America at times reflects the fractured and disjointed existence of some transnationals. Therefore, he feels at one point more "curious and unfamiliar to [him]self" (141). He also wonders if his home has made him shut off from others (193). Later, Hata summarizes what his life has become: "I feel I have not really been living anywhere or anytime, not for the future and not in the past and not at all of-the-moment, but rather in the lonely dream of an oblivion, the nothing-to-nothing drift from one pulse beat to the next, which is really the most bloodless marking out, automatic and involuntary" (320-21). Liminal and diasporic, Hata cannot live anywhere at any time; his traumatic and displaced experiences have made him lost to himself. Lee illuminates this reality through three trends or ailments in Hata's psyche: empty social gestures, a prideful estrangement to others, and several attempts to erase his life through suicidal impulses and personal revisions. 
Accordingly, all immigrants, especially those here through similar circumstances as Hata, encounter psychological difficulties assimilating in America. Immigrants, as Hata confirms on one level, constantly are viewed, judged, and incorporated by the society at large. Hata explains this tendency, this political/visual exchange from mainstream society upon the immigrant, through talking about his business: "[I]t was the generous attitude of the customers that drew me out and gave me confidence, and that every decent and good thing that has come to me while I have lived here is due to some corollary of that welcoming, which I have never lost sight of" (4-5). Hata's identity is formed by his customers' attitude. Subsequently, Lee's final line here takes on double meaning, for Hata never loses "sight" of them and they never stop their "sight" of him. Hata ponders after this admission whether he has "too keenly sought approval and consensus" (5). He concludes this thought, stating that "the past proves a most unstable mirror, typically too severe and flattering all at once, and never as truth-reflecting as people would like to believe" (5). Lee's concept of the "unstable mirror" is important because it symbolizes the immigrant identity that is reflected and refracted back to him/her. "Never as truth-reflecting," this mirror (i.e., a gaze) reifies that slippery identity of those like Hata.

Lee gives an example of this existence when Hata sees another Japanese business man. Hata describes this meeting: "Once, I even met a Japanese gentleman from the San Francisco Bay area, who owned a store that sounded much like mine, and had opened in the very same year" (20). This double makes Hata "think [that] we both brightened on sighting each other" (20). Seeing the other (man), quite figuratively seeing his own reflection here, instantly "brightens" Hata yet leaves him feeling "an unexpected awkwardness" (20). Socially these two Japanese do not fit in with each other: "You would think we would have plenty to discuss, being of like 
race and age and occupation, but our conversation was oddly halting and strained. There was a difficult moment, on being introduced to each other when it was unclear whether we would shake hands or bow" (20). These men should be able to talk freely; however, they cannot and cannot even figure out an appropriate greeting-"as it happened, we exchanged only the mildest pleasantries" (20). For Hata, this discomfort returns to the immigrant's "unstable mirror," or the inability to belong in America:

I first wondered if he felt he wasn't Japanese enough for me, or whether I thought myself not American enough for him. But later on, after returning home, I thought perhaps it was that we felt different from everyone by virtue of being together (these two Japanese in a convention crowd), and that it was this fact that made us realize, for a moment, our sudden and unmistakable sense of not fitting in. (20)

Hata and his double as members of an ethnic/ immigrant minority seem unable to integrate this double consciousness.

Hata admits after this encounter that his comfortable lifestyle is wearing thin. After noting that "this happy blend of familiarity and homeyness and what must be belonging, is strangely beginning to disturb me," (20), Hata begins to interrogate his relationships to his place and others. While initially proud of his rootlessness, Hata comes to find that a problem, stating:

There is something exemplary to the sensation of near-perfect lightness, of being in a place and not being there, which seems of course a chronic condition of my life but then, too, its everyday unction, the trouble finding a remedy but not quite a cure, so that the problem naturally proliferates until it has become you through and through. (289-90) 
This "problem" that becomes "you through and through" corresponds to life as a transnational survivor, drifting upon the forces that put one "in a place [while] not being there." Rationalizing this existence, Hata explains that upon his "decision to leave Japan for good," he did not wish "to think at length about women and intimate relations and companionship, for [he] knew there would be myriad difficulties ahead for [him], in setting up [his] small bit of commerce, and other things in life" (48). ${ }^{5}$ Through retrospection, Hata begins to see that this "chronic condition" needs a "remedy."

Because he is socially incapable, Hata early in life believes that gestures provide substance in his life. However, as Anne Anlin Cheng notes, "social performance" acts as a "theatrical rather than substantive aspect of subjecthood" (559). For example, after exploring the entrails of a pig, he concludes that the soul resides in the flesh and not in the mind: "I have had the thought from time to time that indeed these [referring to a mutilated pig's quivering heart and lungs] were the vessels of the animal's spirit, and that perhaps our souls, too, reside not in our minds but in the very flesh of us, the frank, gray tissue which seems most remarkably possessed of the will to go on, to persist" (247). Preferring to believe that our bodies represent our souls, Hata relies on physical gestures throughout the novel's first half. Yet these formalities subsume his interpersonal connection to others. Sunny (i.e., his daughter) proclaims that her father, "make[s] a whole life of gestures and politeness" (95). Earlier in his life, Captain Ono says similarly: "You [...] too much depend upon generous fate and gesture" (266). Accordingly, Ono explains to Hata that "[t]here is the germ of infirmity in you, which infects everything you touch or attempt" (266). Hata's gestures thus stemmed from a self-constructed Japanese identity that subverted a never fully realized Korean self. Striving to be always someone else, he manages only to become a simulacrum of identity-a Mr. Miyagi (i.e., Asian-American 
actor Noriyuki "Pat" Morita's famous stereotype) for suburban New York. ${ }^{6}$ In fact, in his American "home"town of Bedley Run, "Doc" Hata seems to embrace the stereotype-or as Hamilton Carroll labels, "a profound self-deception" (592)-of the "ideal minority": the respectable Asian other or wise old sage who fastidiously invests and "grooms" his life (137-8), gives calculating responses (130), prompts advice and wisdom (319), and makes America "orientally" exotic (104). ${ }^{7}$ More simply, Hata realizes that he has a developed "an unexpected condition of transparence here, a walking case of others' certitude" (21). Acting out empty gestures and rationalizing them, either for reputation or for adherence to perceived Japanese-Americanness, creates Hata's gesture life, one that limits his connection with others. ${ }^{8}$ His unyielding complacency to remain in the periphery prevents himself "to be part (if but a millionth) of the massing, and [... to] pass through with something more than a life of gestures" (299). Standing on the sidelines of life, in other words, speaks to a latent problem on Hata's part of fitting in. Gestures are thus a means to mask his uncomfortable position in society.

Hata also is a disturbed character, one who at first prides himself on his estranged relationships-a quality that reflects another malady. The slow deterioration in his relationship with Mary Burns offers insight about this tendency. Mary Burns, a widowed, middle-aged neighbor, fosters changes in Hata, however brief. After he recounts their first conversation, he discovers a change emanating from his psyche: "[W]ith Mary Burns I seemed to forget the place where I was. [...] It was an almost memorial sweetness, rising beneath me like a lifting wave, as if it were intent on transporting me, sending me to a place across oceans" (49). Unmoored by her gentle character, Hata does not allow himself to ride this wave to a new place. Instead, he quickly moves away from this liberal "sweetness" to prescribed gestures. Mary Burns fits into his plan for an American life (for the motherless Sunny, 
he claims): "My only real chance was to locate a childless widow who might consider an opportunity for motherhood reason enough to leave her homeland" (51). He admits that "it was obvious how nearly perfect Mary would be as a mother" (313). For Hata, however, his logical disposition does not overrule his socially prescribed gestures. One great example of this occurs during a love scene between Mary and Hata. Upon wandering off together on an "impromptu hike," they begin to kiss "spurring ebullience that caught [them] both off guard" (313). Moving deeper into the nearby woods, they slip (due to Mary's urging) into "a small opening within a thicket, [...] a lair that must have been used by deer" (314). Hata explains the passion that begins: "And we began to kiss, and eventually our hands were purposefully exploring each other, lingering and caressing and soon enough undoing buttons, clasps. It would have been scandalous in town had someone caught us. But it didn't seem that we cared" (314). Constantly posturing or concerned about society's view of him, Hata lets this awareness rest in the scene. However, a deeper hindrance surfaces, for Hata cannot let himself make love to her despite her want, admitting, "I felt awfully young, touching her, and the wanting I had wished never again to know was rushing back to me, a disturbing shiver in my fingers and in my mouth and in my eyes. I stopped everything then" (315). He feels that his passion is "disturbing" and cannot continue. More problematic, they "never [speak] again of what had happened" in this scene (315). The Mary Burns relationship reveals that Hata cannot move beyond his psychological inhibitions or socially determined gestures. He would rather avoid intimacies and confrontations than foster a health relationship at that point in his life.

Similarly, Hata has trouble with Sunny, his adopted daughter, and avoids working through the fissures in their relationship. Lee illustrates this quality early when Hata restores her room after she abandons him: 
I remember patching and repainting the ceiling and walls, making sure to fix all the mars in the plaster. There were larger pocks, into which I found it easy enough to spade the filler. But it was the smaller ones, particularly the tack holes, which seemed to number in the hundreds, [sic] that took the greatest part of my time. In the end, I found myself doing the work in half-foot squares, pressing in the paste with the tip of a finger, smoothing it out, and it wasn't until much later, as l'd drift over the surfaces, that the whole project was quite satisfactorily done. (14-15)

Refashioning Sunny's room represents Hata's denial. He avoids the conflict that made her leave in the first place. Feeling "the whole project" to be "quite satisfactorily done," Hata's tone described above drives away the pain behind losing his daughter. By working "in half-foot squares," Hata systematically blots/erases her out of his life. This act reifies an earlier desire he mentions: "I wanted to hide the real depth of the trouble, put it away not (as Sunny always contended) for the sake of my reputation or standing but so I could try to forget she was my daughter, that she had ever come to live with me and had grown up before my eyes" (98). ${ }^{9}$ He wants to erase her from his life.

Most disturbingly, Hata has several suicidal or psychotic impulses that are deep-seated attempts to separate himself from others-the last type of psychological ailment. Hata's suicidal impulses and moments of erasure begin from the novel's opening sequence. He ponders, like John Cheever's protagonist in "The Swimmer," the domestic, suburban repetition of life, and while believing he could be swimming in neighboring pools, Hata swallows some water (22). Later he explains a desire to breathe water: "Some of us longtime swimmers often wish for ourselves that submerged, majestic flight, feel the near-desire to open one's mouth and relax and let the waters rush 
in deep, hoping that something magical might happen" (277). ${ }^{10}$ Elsewhere Hata faints while visiting Sunny and describes the breathless sensation: “There's a feeling of something like purity again, a razing and renewal, as if I might wholly banish all that I was just a moment ago" (207). For Hata, ending one's breathing allows a twisted vision of rebirth. Later, he wonders if he wants simply to kill himself or transmogrify into "a brand-new life, fresh and hopeful and unfettered" (277). These moments show Hata's latent impulses to end life and to find a "wholly different heart and shell and mien" (277).

It is important to remember that suicide never literally occurs in the book. Still Lee demonstrates other moments of erasure. The novel's early house cleaning scene appears minor at first look. After all, is not Franklin Hata, our narrator of twenty pages, just burning some old, useless documents to warm his chilled body after his morning swim? On the surface, he is doing just that. However, examining the contents and method of his burning reveals a covert act of erasure. Hata burns "the decades-old files and papers and other expired and useless documents" which includes "such stuff as canceled checks and mortgage and bank statements" (24). Although these items appear to be insignificant and the act itself normal and necessary, the narrator is erasing records of his existence, proof of his (American) residency. Similarly, this scene corresponds to the earlier one about Sunny's room. In both cases, Hata tries to get rid of evidence of life-perhaps he is exorcising a death wish.

Earlier in life while invading with the Japanese army, Hata similarly denies or erases his Korean heritage and identity, which Carroll deems a "repudiation of his own heritage" (603). When the Korean comfort woman Kkutaeh explicitly states, "You are a Korean,"” he replies, "No [...] I am not"” (234). Erasing his original background, he assumes a Japanese identity, stating proudly: "'I'm a medical officer of the Imperial Forces, and there's nothing else to be said. [...] I spoke some 
Korean as a boy. But then no more" (235). ${ }^{11}$ He also denies his Korean name (235). On a practical level, this denial represents Hata's survival under the Japanese hegemonic regime. (After all, his birth parents inculcate an idea of Japanese superiority (235). To succeed in Japan, he has to deny his Korean identity.) On a psychological level, however, Hata's dismissal of the Korean language represents a struggle to come to terms with his place in Japanese society. Because of his slippery existence as a Japanese soldier and his even messier understanding of his Korean humanity, Hata cannot give in to himself and help Kkutaeh escape forced prostitution. ${ }^{12}$ Even when he is negotiating and trying to take a stand for her, he suddenly and unconsciously salutes Kkutaeh's tormentor, Captain Ono (264).

Hata holds long-lasting guilt over Kkutaeh's death and his culpability in it. To assuage this overwhelming pain, he adopts Sunny. Mark Jerng in his "Recognizing the Transracial Adoptee: Adoption Life Stories and Chang-rae Lee's A Gesture Life" elaborates on the issue of adoption in the novel, noting that because of "confusions of temporality and the ambivalence of address" "adoption is figured in terms of transference" (45)..$^{13}$ Jerng continues and finds transference in the "ambivalent ethical relation between Doc Hata and $K$ to the adoptive relation between Hata and Sunny" (53). Indeed, Hata explains to his adoption agent "how [he] always hoped for a daughter, the words suddenly streaming from [his] mouth as though [he had] long practiced the speech. [He] found [him]self speaking of a completeness, the unitary bond of a daughter and father. Of harmony and balance" (74). An almost unconscious admission, his explanation speaks to his desire to (re)create a love with a "girl" (i.e., Kkutaeh). Mary Burns notices this "transference," to borrow Jerng's term: “'[l]t's as if she's a woman to whom you're beholden, which I can't understand. [...] You adopted her. But you act almost guilty, as if she's someone you hurt once, or betrayed, and now you're 
obliged to do whatever she wishes, which is never good for anyone, much less a child"' (60). Prophetic and accurate, this quote reinforces Hata's psychological replacement of Kkutaeh with Sunny.

Consequently, Hata's role in Sunny's abortion, the last major act of erasure, illustrates an extremely unhealthy attempt to reorder his past. Lee parallels Kkutaeh's mutilation and Sunny's partial-birth abortion to indicate further Hata's psychological conflation of the two characters. Jerng explains, "The double-movement of the narrative, oscillating as it does between looking forwards and looking backwards, acts out this model of transference in narrating the adoptive relation" (55). For example, Hata expects Sunny to come from a "hardworking, if squarely humble, Korean family" (204) similar to Kkutaeh's (248). Even though there is evidence that Sunny is not Kkutaeh, Hata cannot move beyond Sunny's impure miscegenation, or her "blight." According to him, Sunny's “hair, her skin, were there to see, selfevident, and it was obvious how some other color (or colors) ran deep within her" (204). He also wants Sunny and himself to have a "natural affinity" (204) much as he thought he had with Kkutaeh, "a special correspondence between us, an affinity of being" (263). Of course, Hata and Sunny have no such relationship. Even in parenting, Hata works against the image Kkutaeh presented of her father, who was indifferent, cold, and untouching (245). As a result, Hata tries to be the perfect father: "overgenerous, [...] extremely permissive and obliging," and hands-on (71). Again, Sunny is not Kkutaeh. Sullen and rebellious, Sunny turns out to despise his lessons and overbearing style. ${ }^{14}$

Hata's largest attempt at psychological reconcilement with Kkutaeh is Sunny's abortion. He needs to erase his young mistake. Earlier in his life, Kkutaeh wanted Hata to kill her and end her misery as a "comfort woman" (301). Hata failed to do this, and she was gang-raped and dismembered. Hata (dis)remembers finding her: 
I could not feel my hands as they gathered, nor could I feel the weight of such remains. And I could not sense that other, tiny, elfin form I eventually discovered, miraculously whole, I could not see the figured legs and feet, the utter, blessed digitation of the hands. Nor could I see the face, the perfected cheek and brow. Its pristine sleep still unbroken, undisturbed. And I could not know what I was doing, or remember any part. (305)

Retracing his discovery through negation, denial, and avoidance, Hata cannot accept that his inaction causes Kkutaeh's most horrible reality: her fetus is taken from her. ${ }^{15}$ In the more recent past, Sunny's abortion (forced upon her by Hata) stands for another adoptive act of compensation for Kkutaeh and a covert attempt to erase guilt for Hata. The clinician Dr. Anastasia has tremendous reservations about performing Sunny's abortion (for she is well over twenty-eight weeks). ${ }^{16}$ Hata insists that the abortion happen, claiming that she has failed to finish high school, that she has no job, and that the father is a (black) drug addict (342). Beyond this insistence, Hata also assists the doctor (343). He does this in hopes that the "similar things" he saw earlier in life can be put right (344). Sunny's abortion, however, merely repeats the violence done to Kkutaeh.

Such a horrible moment would certainly leave the reader despising Hata. Yet Lee begins a redeeming process through physical and psychological recuperation. Hata's lung condition from the opening sequence proves ironically healthy. Presently Hata offers a self-diagnosis: "From what I know and feel, I'm almost certain that I'm pleuritic, as my lungs don't seem to be improving the way they should. My chest feels leaden and straightjacketed and generally out of sorts. [...] And then there is the other, unrelated complication that has arisen, one far worse in my mind (and spirit-sapping), which is that I suddenly have an onset of the shingles" (67). Lee's 
language of psychological/physical imprisonment (i.e., "straightjacketed," "out of sorts," and "spirit-sapping") indicates a transition Hata has into introspection. The smoke inhalation and its lung irritation closes Hata's active physical life; reflection and analysis replace fitness and action. One small example demonstrates Hata's change. Hata contemplates the theme from Cheever's "The Swimmer" and begins to identify himself with that character: "I suddenly have the thought that I'm not swimming in my own pool at all, but am someplace else, in a neighboring pool or pond" (22). Even though this reference has been explained earlier in this essay, Hata provides an exegesis of the story offering three interpretations: the swimmer engages in a quest only to find spiritual disillusionment, he is mad or drunk and swims to escape from the "realities of his fallen station," or he metaphorically passes the "seasons" of his life through swimming (23). This literary guesswork opens a new way to see Hata's life. Hata's character moves from activity, or gesture, to reflection. In a way his lung condition affords time to contemplate his psyche. Unlike Cheever's protagonist, Hata is able to stop at the roadside and return home before it is too late.

Hata begins his own spiritual quest to promote a healthier, recuperated self. After landing in the hospital, Hata starts a recovery in mind and body. Through the return of repressed memories, Hata becomes a new character, one who fully understands himself and becomes healed. Theorist Cassie Premo Steele, in her book We Heal from Memory, reminds us that "[i]t is memory, as both a problem and a promise, that forms and allows us to form our individual and collective identities" (2). ${ }^{17}$ In essence, by casting his mind into his darkened past, Hata tells both an individual story and that of collective transnationals. Specifically, contemplating his relationship with Kkutaeh allows Hata to come to terms with his Korean heritage. Reconnecting with Sunny begins to resolve his guilt. Selling his house impels Hata into 
a new life. By the novel's ending, a whole set of new, substantive "gestures" usher in a new character.

For Hata, Kkutaeh and her memory link him to a silenced Korean identity. His description of Kkutaeh even suggests an infantile fascination: "After some time I turned to see that she had finally fallen asleep, her knees drawn up toward her chest. I stared at her for quite a long moment, taking in her figure and loosely fisted hands and the serene, pale oval of her face, when she slowly opened her eyes" (240). Kkutaeh's body becomes a substitute for the Korean motherland. Although he denied his knowledge of Korean earlier, he admits, before gazing at her, that Korean was his "childhood language" (239). The Lacanian gaze reinforces his out-of-placeness around her, as Lee extends. Hata's gazing upon Kkutaeh, or his la objet petit $a$, awakens a desire within him: he feels "a certain connection to her, not in blood or culture or kind, but in that manner, I suppose, that any young man might naturally feel for a young woman" (239). ${ }^{18}$ This "connection" with her transforms into possession, an unviolent sexual assault:

I crawled around and lay down behind her, so that our bodies were aligned, nestled like spoons. She was warm and still and I gently pressed my face into the back of her neck and breathed in the oily musk of her hair. And it was so that I finally began to touch her. I put my hand on the point of her hip and could feel all at once the pliancy of it and the meagerness and the newness, too. I felt bewildered and innocent and strangely renewed, as though a surge of some great living being were coursing up my arms and spreading through my unknowing body. [She remains still, faking sleep]. I kissed as much of her body as was bared. I kissed her small breasts, which seemed to spill a sweet, watery liquid. I gagged but did not care. [...] And when I was done I felt the enveloping warmth of a fever, its languorous 
cocoon, though when I gazed at her shoulder and back there was nothing but stillness, her posture unchanged, her skin cool and colorless, and she lay as if she were the sculpture of a recumbent girl and not a real girl at all. (259-60)

This passage reveals many ideas about the protagonist. First, he is sexually naïve: he takes advantage of her, fails to recognize the obvious indication of her pregnancy, and associates this assault with love (saying "I love you" both in Japanese and Korean afterward). While he may feel "renewed" by his stealthy intercourse, she reciprocates nothing "as if she is a sculpture." Secondly, Hata misunderstands the tenderness. The "enveloping warmth of a fever" he feels, this slow-opening "cocoon"-a word that suggests a locked-up kernel of rebirth to himcorresponds to orgasm, not love. And though he notices her tears following the assault (261), he cannot console her then.

Years later, Hata revises his intentions. Slipping into third person, the protagonist finds a new chrysalis to open, stating, "He did not yet know it, but he hoped that if he could simply be near to her, near to her voice [or her language] and to her body-if never even touching her-near, he thought, to her sleeping mind, he might somehow be found" (240). A need to protect or preserve her, found through introspection and time, proffers the chance to "be found." Perhaps Hata wishes he could have been "outed" for his ethnicity and perish with her.

Hata is given an opportunity to mourn Kkutaeh and to reconnect with his Korean heritage through a metaphoric sequence of considerable importance. Lee provides an ethereal backdrop for Hata's grief: "Now and then, I sometimes forget who I really am. [...] I lose all sense of myself. I forget what it is I do, the regular activity of my walk and my swim and my taking of tea, the minor trappings and doings of my days, what I've made up to be the token flags of my life. I forget why it is I do such 
things, why they give me interest or solace or pleasure" (285). Hata begins to analyze his gestures, or "the token flags of [his] life." He continues and describes a journey: "Then I might get up in the middle of the night and dress and walk all the way to town, to try to figure once again the notices, the character, the sorts of actions of a man like me, what things or set of things define him in the most simple and ordinary way" (285). In this fugue state, he finds himself defenseless, open to long-lost memories. Indeed, he admits following one excursion to town that "K has finally come back for [him]" and that at "moment [...] [he] feel[s] at home" (286). Lee ambiguously labels this apparition " $K$ " to represent both Kkutaeh and Korea. ${ }^{19}$ Lee chooses to use "for" to suggest that this "K" will be provoking him homeward to her, to his past, to Korea. Hata remains surprisingly passive until he spurns a conversation with the " $\mathrm{K}$ " ghost: she asks, "Will we be going away soon, Lieutenant?"'. He responds with "“Where would we be going to, K?"”. "'I had hoped we would finally travel to all the places we have spoken of. To Shanghai, and Kyoto, and perhaps even Seoul. Or some other place, "' she answers (287). Hata's fantasy indicates his desire to revise history, to reenact a wish fulfillment from his past. ${ }^{20}$ Shanghai, Kyoto, and Seoul, the cultural centers of their Asian identities, are the places these characters could journey "to try to figure once again the notices, the character, the sorts of actions of a man like [him], what things or set of things define him in the most simple and ordinary way" (285). Lee reminds the reader that Hata cannot find solace for his pain here; after Hata and " $K$ " end the conversation, she joins him in bed only to vanish. ${ }^{21}$ In an attempt to promote a lasting relationship with his past, Hata makes a gesture that promises change: he sells his house.

An object of pride, the house emblemizes Hata's American life. Aside from its function in his multiple erasures, the house becomes a vestige of stagnant life, "the penultimate trap of living," according to Hata (287). 
Indeed, the house maintained through Hata's constant grooming and gestures reifies an unlived-in or (un) comfortable existence in America. He even finds later in life that his house is "a lovely, standing forgery, pristine enough and old enough that it passes most every muster" (352). Lee further encourages Hata's recognition of this "forgery" after he returns from the hospital. Feeling displaced and estranged, Hata begins to see the house with its "showcase, immaculate, pristine and classic condition, appearing just as though I have not lived there every day for the last thirty years of my life" (119). Acknowledging this peculiar feeling of displacement shows Hata's growth through his medical/psychological recuperation. He learns that the house stands for an inner disconnection, a sign that there is something missing in his life. Lee hints at this point early. Hata explains an alienation, "I keep stepping outside my house, walking its grounds, peering at the highly angled shape of its roofs, the warm color and time-textured facade, looking at it as though I were doing it for the very first time, when I wondered if I would ever in my life call such a house my home" (22). Interrogating the idea of this house as a home, Lee anticipates the novel's ambiguous last line- "almost home"-here (356). Hata's house, as it is constituted and maintained, is not a home but "a lovely, standing forgery" (352). Therefore, selling the house allows him to move on in life, to end his American malaise, and to pay off several symbolic, psychological debts.

Whereas Hata's selling of the house represents a moving forward, the repairs he forges in the relationships with Sunny and his grandson, Thomas, signify a moving backward, a final healing of his past. As we have seen, Hata and Sunny's relationship was dysfunctional from the start-based largely on Hata's ill-formed attempt to replace Kkutaeh. The late amelioration of this relationship plays an integral part in Hata's psychological recuperation. Thomas works as the catalyst that initiates the healing process. When Sunny states that Thomas has saved her "over and 
over, a thousand times," Hata affirms and realizes "a bloom of well-being is opening immediately and fully in [his] heart, the kind of pleasure [he has] hitherto only read about or imagined, what must be the secret opiate of all fathers and mothers" (283). As grandfather, Hata truly understands the benefits of fatherhood. Promises of rebirth seem to shine upon Hata, for he has a "hope of a familial continuation, an unpredictable, richly evolving to be" (334). Aside from Lee's use of the infinitive here, which suggests an unending existence, the author has Sunny carry a white paper bag. A figurative white flag of truce, this bag redirects the novel's motif of black flags, "banner[s] [that warn] of a contagion within." Instead of warning of impending doom and "spreading death," this marker signals a new beginning in Hata's relationship with his daughter (224).

Hata has encountered his repressed memories and has tackled the overwhelming guilt he has had in his life. Lee, however, provides a concrete example to show Hata's change. Again, I return to the house. Selling his house becomes a secret philanthropic gesture: he gives money for the Hickeys' bankrupt business and their ailing son Patrick. Unlike earlier gestures in the novel, this gesture connects Hata to his community in a new way, not as flourishes of self-aggrandizing and conformity. Perhaps Cheng explains this point best: "We might call this final litany a choice for active passivity in the most earnest sense: not the passive aggression that motivated much of Hata's actions in the past [...] but instead an active refusal to act any further in bad faith" (571). Moreover, the remainder of the profits will allow Hata to travel and address other ills. He ends the narrative with more promises: “Perhaps I'll travel to where Sunny wouldn't go, to the south and west and maybe farther still, across the oceans, to land on former shores" (355-6). Like his fantastic encounter with " $K$," Hata ponders the possibility to return to Asia. Yet, he will not be fooled this time by false dreams. He says, "I won't seek out my destiny or 
fate" or "find comfort in the visage of a creator or the forgiving dead" (356). By this point, he realizes revisions and repressions will not change his past; a more simplistic life awaits him. The novel's last paragraph illustrates these points: "Let me simply bear my flesh, and blood, and bones. I will fly a flag. Tomorrow, when this house is alive and full, I will be outside looking in. I will be already on a walk someplace, in this town or the next or one five thousand miles away. I will circle round and arrive again. Come almost home" (356). This passage reverses many of the themes of transnational and psychological alienation and ailments throughout the narrative. Fulfilling his idea that the "soul resides in the flesh" (247), Hata now will own the corporeal properties of his life, leading to a spiritual health. Furthermore, he surely will fly a white flag to let the world know that there is no longer disease and destruction within him. Finally, he will journey, no doubt traveling the five thousand miles to Shanghai, Kyoto, and Seoul to fulfill Kkutaeh's desire, and arrive again. Significantly, Hata moves on from his house, which he detaches from his gaze. To "come almost home," means Hata has found peace and place. This journey will reveal that he is not as lost as he once was. ${ }^{22}$

In some ways, A Gesture Life chronicles the awakening of a damaged man. Sparked by accident, Hata's recuperation opens a vast reservoir of loss and trauma in their various forms. Hata "arrives" by the narrative's end to have improved relationships with his daughter and grandson. He has worked through his role in the Kkutaeh fiasco. He has sold his house to provide opportunities for the future. We learn that transnational souls like Hata's can be recuperated to become new and healthier.

\section{Notes}

1 David Cowart explains, “Not comfortably Korean, Japanese, American, or Chinese, Franklin Hata is a casualty of the twentieth century[-] he can never [...] escape the ugliness he has witnessed" (80). 
2 On the other hand, Young-Oak Lee notes that Hata "[b]ecomes an American citizen" (147).

3 In another interview, Adrienne Mong notes that "Lee admits he feels the same way as his characters, out of place."

4 For an extended discussion of trauma, see Hamilton Carroll's "Traumatic Patriarchy: Reading Gendered Nationalisms in Chang-Rae Lee's A Gesture Life." Carroll makes this claim: "In A Gesture Life, trauma functions as an alternative form of memory and history. Understood as a disruption of nationally oriented referential history, the traumatic narrative orchestrates the production of a historiography that exposes the workings of gender and race that cut between and across the novel's doubled national locations" (595).

5 Hata even suggests that perhaps sub-urban America generally fosters this disconnection: " $[\mathrm{A}] \mathrm{s}$ it mostly is in towns like Bedley Run, and particularly on streets like ours, being neighbors means sharing the most limited kinds of intimacies, such as sewer lines and property boundaries and annual property tax valuations. Anything that falls into a more personal realm is only tentatively welcomed" (44).

6 After all, his literary antecedent, Jay Gatsby, enacts a similar project to disguise his middle-western, working class roots.

7 This example references the odd encounter between Hata, searching for Sunny at a teenage party, and a girl behind a veiled bed. During intercourse, the girl fixates on Hata as she reaches climax to his image. The "exotic" I refer to here is largely based on Sheng-Mei Ma's The Deathly Embrace and Frantz Fanon's Black Skin, White Masks. Both texts show how race (i.e., Otherness) sexually attracts the majority.

8 Cheng agrees here, stating: "The novel features a protagonist named Franklin Hata, who has spent his entire life donning various forms of camouflage and whose life is structured by the struggle between guilt and desire, between self-erasure and self-assertion" (558).

9 Later, he even describes her as his "former daughter" (132).

10 In another moment of literary homage, Lee borrows language from Kate Chopin's The Awakening. Specifically, Edna Pontellier's watery suicide reads, "The foamy wavelets curled up to her white feet, and coiled like serpents about her ankles. She walked out. The water was chill, but she walked on. The water was deep, but she lifted her white body and reached out with a long, sweeping stroke. The touch of the sea is sensuous, enfolding the body in its soft, close embrace. [. . .] She looked into the distance, and the old terror flamed up for an instant, then sank again" (109).

11 Although he says this under public discourse as the medical officer, he privately speaks to her "in her own language" of Korean when she is checked into the camp (232).

12 Cheng elaborates this idea, "Fulfilling K.'s request would have meant breaking rank, transgressing not only military code but also his Japanese and masculine identifications" (562). 
13 Jenrg anticipates my argument stating: "Two narrative drives co-exist uneasily within the text: Doc Hata's drive to belong and find closure for his life as an assimilated Japanese American in the suburban town of Bedley Run; and his constant returns to and flashbacks of the past, the traumatic events of his participation as a Japanese soldier in World War II. What connects these two narrative movements in Doc Hata's adoption of a Korean girl, Sunny" (51-2).

14 This behavior results from Hata's "continuation of a series of lifelong psychic struggles over social, ethnic, and sexual identifications" (Cheng 564).

15 Consult Cheng for another explanation, regarding the interpretation of Kkutaeh's body (563).

16 This peculiar name perhaps comes back to Jerng's idea of temporal confusion. Maybe Hata wants to filter this scene as both a fantasy and as anesthesia.

17 Steele argues that poetry allows victims and others to begin the process of healing.

18 See Cheng for an explanation of Lacan's Gaze (566-570).

19 Carroll also makes this point, "Symbolically [...] the ' $\mathrm{K}$ ' of Kkutaeh is the ' $\mathrm{K}$ ' of Korea" (604).

20 Hata also superimposes northeastern Asia into this setting. For instance, he begins to smell the scent of "the sea, a warm and gentle southern sea" (288), and he sees his yard become a "broad continent" and his pool "a whole ocean" (289).

21 Lee gives another glimpse of this theory during the conversation when Hata objects to "K's insistence on being with him in "some other place." He asks, "'But I have to wonder, why being here is so abhorrent to everyone but me? We have everything that we require. And much more. We have an impressive house and property in the best town in the area, where we are happily known and respected. We have ample time and quiet and means. I have tried as hard as I can to provide these things, and we have been welcomed as warmly as anyone can expect. Everything is in delicate harmony" (287). She answers that "'nothing is wrong with it" " but that she "'cannot die here"" (287). She seems to know the importance of her cultural heritage more than he does at this point.

22 David Cowart suggests that Hata's use of "home" works as a "kind of absconding signified" in the last line (80). Cowart also suggests that America can be Hata's "almost home" (80), but I believe the where is not important for Hata's journey. What is more important is that Hata's elusive home does exist.

\section{Works Cited}

Carroll, Hamilton. "Traumatic Patriarchy: Reading Gendered Nationalisms in Chang-rae Lee's A Gesture Life." Modern Fiction Studies 51.3 (Fall 2005): 592-616.

Cheng, Anne Anlin. "Passing, Natural Selection, and Love's Failure: Ethics of Survival from Chang-rae Lee to Jacques Lacan." American Literary History 17.3 (Fall 2005): 553-74. 
Chopin, Kate. The Awakening. A Norton Critical Edition. $2^{\text {nd }}$ ed. Ed. Margo Culley. New York: Norton, 1994.

Cowart, David. "New Americans: Recent Immigrant Writing." Roots and Renewal: Writings by Bicentennial Fulbright Professors. Ed. Mark Shackleton and Maarika Toivonen. Helsinki: Hakapaino, 2001. 77-85.

Fanon, Frantz. Black Skin, White Masks. Trans. Charles Lam Markmann. New York: Grove, 1967.

Felman, Shoshana, and Dori Laub. Testimony: Crises of Witnessing in Literature, Psychoanalysis, and History. New York: Routledge, 1992.

Garner, Dwight. "Adopted Voice: An Interview." The New York Times on the Web 5 September 1999. Web. 30 June 2008 <http://www.nytimes.com/books/99/09/05/reviews/ 990905.05garnet.html>.

Jerng, Mark C. "Recognizing the Transracial Adoptee: Adoption Life Stories and Chang-rae Lee's A Gesture Life." MELUS 31.2 (Summer 2006): 41-67.

Lee, Chang-rae. A Gesture Life: A Novel. New York: Riverhead, 1999.

Lee, Young-Oak. "Gender, Race, and the Nation in A Gesture Life." Critique: Studies in Contemporary Fiction 46.2 (Winter 2005): 146-59.

Ma, Sheng-Mei. The Deathly Embrace: Orientalism and Asian American Identity. Minneapolis: University of Minnesota Press, 2000.

Mong, Adrienne. "Interview: Profile: Chang-rae Lee: A Writer's Life." Far Eastern Economic Review 9 November 2000. Web. 7 February 2002

<http://www.feer.com/cgi-bin/HSE/HSE.cgi?...current. html;geturl;terms=Chang-Rae $\mid$ Lee>.

Steele, Cassie Premo. We Heal From Memory: Sexton, Lorde, Anzaldúa and the Poetry of Witness. New York: Palgrave, 2000. 